Available online at https://jurnal.stmikroyal.ac.id/index.php/jurdimas

\title{
PENDAMPINGAN PROGRAM PHBS BAGI ANGGOTA PALANG MERAH REMAJA (PMR) MADYA DI WILAYAH BINAAN PMI KOTA MAGELANG
}

\author{
Eka Sakti Wahyuningtyas $^{1^{*}, \text { Estrin Handayani }}{ }^{2}$ \\ ${ }^{1}$ Program Studi Ilmu Keperawatan FIKES , Universitas Muhammadiyah Magelang \\ ${ }^{2}$ Program Studi Diploma Keperawatan FIKES , Universitas Muhammadiyah Magelang \\ email:*ekasakti@ummgl.ac.id
}

\begin{abstract}
The emergence of some diseases that often attack school-age children, it turns out generally related to Clean and Healthy Life Behavior (PHBS). Other schools function as a place of learning and can also be a threat of disease transmission if not managed properly. More than that, school age for children is also a vulnerable period of various diseases. Therefore, the planting of PHBS values in schools is an absolute necessity and can be done through an approach with the PMR (Youth Red Cross) which is assisted by the local PMI (Indonesian Red Cross. In the hope that PMR members can carry out the Promotion Efforts to realize Clean and Healthy Life Behavior in the school environment to realize a Healthy School. The specific target of this activity will involve 30 members of the Intermediate PMR in the PMI Area of Magelang City. This activity includes the provision of material related to the technique of washing hands properly and properly and maintaining personal hygiene, the dangers of cigarettes and drugs, HIV AIDS, and the use of healthy latrines. Implementation with simulations for the application of Clean and Healthy Behavior through campaigns and demonstrations.
\end{abstract}

Keywords: PHBS, PMR, school

\begin{abstract}
Abstrak: Munculnya sebagian penyakit yang sering menyerang anak usia sekolah, ternyata umumnya berkaitan dengan Perilaku Hidup Bersih dan Sehat (PHBS). Sekolah selain berfungsi sebagai tempat pembelajaran juga dapat menjadi ancaman penularan penyakit jika tidak dikelola dengan baik. Lebih dari itu, usia sekolah bagi anak juga merupakan masa rawan terserang berbagai penyakit. Oleh karena itu, penanaman nilai-nilai PHBS disekolah merupakan kebutuhan mutlak dan dapat dilakukan melalui pendekatan dengan PMR (Palang Merah Remaja) yang merupakan binaan dari PMI (Palang Merah Indonesia) setempat..Target khusus kegiatan ini akan melibatkan 30 anggota PMR Madya di wilayah Binaan PMI Kota Magelang. Kegiatan ini meliputi pemberian materi terkait teknik mencuci tangan dengan baik dan benar serta menjaga kebersihan diri, Bahaya Rokok dan Napza, HIV AIDS, serta Penggunaan Jamban Sehat. Implementasi dengan adanya simulasi untuk penerapan Perilaku Hidup Bersih dan Sehat melalui bentuk kampanye dan demonstrasi. Tujuan kegiatan pengabdian ini adalah meningkatkan pemahaman dan perilaku sasaran dalam memahami serta menerapkan perilaku hidup bersih dan sehat dan dapat mengaplikasikan dalam upaya menjaga kesehatan lingkungan sekolah dengan menghindari perilaku-perilaku yang beresiko menimbulkan penyakit.
\end{abstract}

Kata kunci: PHBS, PMR, sekolah 
Available online at https://jurnal.stmikroyal.ac.id/index.php/jurdimas

\section{PENDAHULUAN}

Munculnya sebagian penyakit yang sering menyerang anak usia sekolah, ternyata umumnya berkaitan dengan Perilaku Hidup Bersih dan Sehat (PHBS). Sekolah selain berfungsi sebagai tempat pembelajaran juga dapat menjadi ancaman penularan penyakit jika tidak dikelola dengan baik. Lebih dari itu, usia sekolah bagi anak juga merupakan masa rawan terserang berbagai penyakit. Oleh karena itu, penanaman nilai-nilai PHBS disekolah merupakan kebutuhan mutlak dan dapat dilakukan melalui pendekatan dengan PMR (Palang Merah Remaja) yang merupakan binaan dari PMI (Palang Merah Indonesia) setempat.

PMR merupakan Palang Merah Remaja yang didirikan oleh Palang Merah Indonesia (PMI), sebuah perhimpunan nasional Indonesia yang bergerak dibidang sosial kemanusiaan. PMR Madya merupakan unsur anggota dengan tingkatan pelajar Sekolah Menengah Pertama dan usia anggotanya 12-15 tahun. PMR memiliki Tri Bhakti yaitu salah satunya adalah meningkatkan keterampilan hidup sehat. Dengan harapan anggota PMR dapat melaksanakan Upaya Promosi mewujudkan Perilaku Hidup Bersih dan Sehat di lingkungan sekolah untuk mewujudkan Sekolah Sehat. PMI sendiri memiliki program Sekolah Sehat sehingga PMR memiliki peranan dalam melaksanakan serta mewujudkan kesehatan di lingkungan sekolah.

Perilaku Hidup Bersih dan Sehat disekolah adalah upaya untuk memberdayakan siswa, guru, dan masyarakat lingkungan sekolah agar mengetahui, memiliki kemauan, dan mampu mempraktikan Perilaku Hidup Bersih dan Sehat, serta berperan aktif dalam mewujudkan sekolah sehat. Indikator PHBS di sekolah diantaranya mencuci tangan dengan air yang mengalir dan memakai sabun, mengkonsumsi jajanan sehat di kantin sekolah, menggunakan jamban yang bersih dan sehat, olahraga yang teratur dan terukur, memberantas jentik nyamuk, tidak merokok di sekolah, menimbang berat badan dan mengukur tinggi badan setiap bulan, membuang sampah pada tempatnya.

Sasaran pembinaan Perilaku Hidup Bersih dan Sehat di lingkungan sekolah meliputi siswa, warga sekolah (kepala sekolah, guru, karyawan sekolah, komite sekolah dan orang tua siswa), dan masyarakat lingkungan sekolah (penjaga kantin, satpam,dan lain-lain). PMR Madya diharapkan dapat menjadi kader perubahan untuk mngurangi perilaku beresiko menurunkan angka derajat kesehatan anak sekolah serta menghindari perilaku beresiko seperti merokok di usia dini sesuai data terbaru Global Youth Tobacco Survey (GYTS) tahun 2014 bahwa 8,3 persen pelajar Indonesia sudah punya kebiasaan merokok, dengan 33,9 persen berjenis laki-laki dan 2,5 persen perempuan pada pelajar tingkat SLTP berusia 13-15 tahun, serta penyalahgunaan NAPZA, dan penyakit lain seperti Diare dan lain-lain (GYTS, 2014).

Upaya Promosi Kesehatan merupakan upaya untuk meningkatkan kemampuan masyarakat melalui proses pembelajaran bersama masyarakat, khususnya masyarakat pendidikan di sekolah melalui Palang Merah Remaja (PMR). Promosi kesehatan ini dilakukan agar mereka dapat menolong dirinya sendiri, serta mengembangkan kegiatan yang bersumber pada masyarakat, sesuai dengan kondisi sosial budaya setempat dan didukung oleh kebijakan secara internal maupun lingkungannya yang berwawasan kesehatan (Kesehatan, Universitas, \& Ratulangi, 2017). Dalam konteks menolong diri sendiri dimaksudkan bah- 
Available online at https://jurnal.stmikroyal.ac.id/index.php/jurdimas

wa masyarakat sekolah mampu berperilaku mencegah timbulnya masalahmasalah kesehatan, memelihara dan meningkatkan derajat kesehatan serta mampu pula mengatasi apabila masalah kesehatan tersebut terlanjur terjadi di lingkungan sekolah.

Berdasarkan hal tersebut, maka akan diadakan kegiatan pengabdian kepada masyarakat dengan tema penanaman nilai- nilai perilaku hidup bersih dan sehat. Kegiatan tesebut akan melibatkan 30 anggota PMR Madya di wilayah Binaan PMI Kota Magelang. Kegiatan ini meliputi pemberian materi terkait teknik mencuci tangan dengan baik dan benar serta menjaga kebersihan diri, Bahaya Rokok dan Napza, HIV AIDS, serta penggunaan jamban sehat. Implementasi dengan adanya simulasi untuk penerapan Perilaku Hidup Bersih dan Sehat melalui bentuk kampanye dan demonstrasi.

Mitra pada kegiatan pengabdian masyarakat ini adalah Palang Merah Remaja (PMR) Madya di Wilayah Binaan PMI Kota Magelang. Masalah yang dapat kita lihat dari situasi di atas adalah masih kurangnya pengetahuan dan perlunya penerapan perilaku hidup bersih dan sehat dalam lingkungan sekolah. Hal tersebut diungkapkan mitra (Pembina PMR Madya dari Korps Sukarelawan PMI Kota Magelang) bahwa sebagian besar anggota PMR Madya masih perlu mendapatkan pengetahuan terkait beberapa indikator Perilaku Hidup Bersih dan Sehat di lingkungan sekolah mereka. Penanaman nilai-nilai PHBS di sekolah merupakan kebutuhan mutlak dan dapat dilakukan melalui pendekatan lewat PMR sebagai salah satu bentuk Tri Bhakti PMR yaitu menjaga kesehatan lingkungan. Hal ini tentu akan berdampak pada terciptanya sekolah yang bersih dan sehat sehingga siswa, guru dan masyara- kat lingkungan sekolah terlindungi dari berbagai gangguan dan ancaman penyakit.

Sasaran dalam kegiatan pengabdian kepada masyarakat ini adalah para siswa yang tergabung dalam Palang Merah Remaja tingkat Madya dalam wilayah Binaan PMI Kota Magelang. Berdasarkan masalah mitra yang dikemukakan sebelumnya, maka tujuannya adalah meningkatkan pemahaman dan perilaku sasaran dalam memahami serta menerapkan perilaku hidup bersih dan sehat dan dapat mengaplikasikan dalam upaya menjaga kesehatan lingkungan sekolah dengan menghindari perilaku-perilaku yang beresiko menimbulkan penyakit. Dengan ini, sasaran akan mampu menerapkan atau mencapai indikator perilaku hidup bersih dan sehat apabila telah mendapat bekal pengetahuan serta menerapkan dalam lingkungan sekolah dan untuk mewujudkan bagian dari Progam Palang Merah Indonesia sebagai perhimpunan Nasional Indonesia yang bergerak dibidang sosial kemanusiaan salah satunya adalah dengan Program PHBS dalam unsur PMR khususnya. Capaian ini akan menjadi referensi bagi pengabdianpengabdian selanjutnya sebagai bahan untuk mengembangkan manajemen PHBS pada tingkatan unsur PMI lainnya serta masyarakat umum sebagai bagian dari perawatan dan pemeliharaan kesehatan di wilayah Magelang.

\section{METODE}

Sasaran dari program ini adalah Palang Merah Remaja (PMR) Madya di Wilayah Binaan PMI Kota Magelang. Namun karena keterbatasan dana dan waktu, hanya 30 anggota perwakilan PMR Madya yang diikutsertakan dalam 
Available online at https://jurnal.stmikroyal.ac.id/index.php/jurdimas

kegiatan. Salah satu tahap dalam kegiatan ini adalah pelatihan dimana sasaran dilatih untuk menerapkan salah satu perilaku hidup bersih dan sehat dengan mencuci tangan yang benar sesuai petunjuk WHO. Secara umum kegiatan ini dapat dilihat pada gambar berikut.

\section{INDIKATOR}

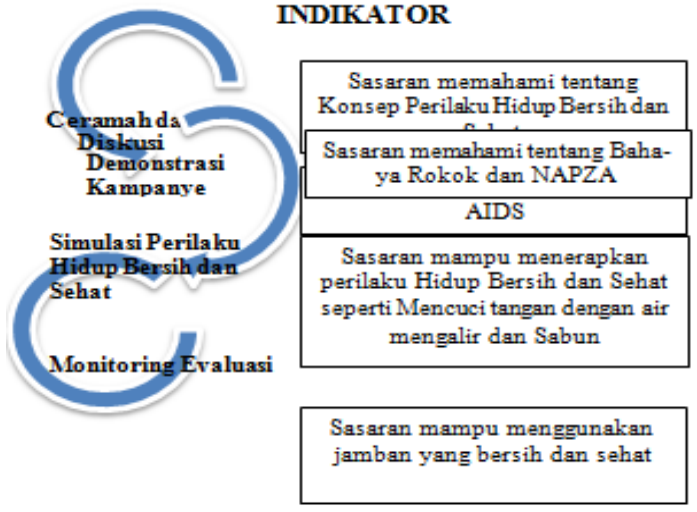

Gambar 1. Metode Pelaksanaan Pengabdian

Pelaksanaan kegiatan terdiri atas beberapa materi kegiatan dengan alokasi waktu 3 (tiga) bulan pelaksanaan Program Kemitraan Universitas. Metode yang akan dilaksanakan meliputi ceramah, diskusi, demonstrasi, simulasi perilaku hidup bersih dan sehat dalam berbagai kasus, serta monitoring evaluasi dalam penerapan PHBS di wilayah lingkungan Sekolah.

Berikut adalah penjelasan pelaksanaannya berdasarkan gambar di atas.

1. Ceramah dan Diskusi

Sasaran akan terlibat dalam diskusi terkait permasalahan dalam pembelajaran dan terkait konsep PHBS, Bahaya Rokok dan NAPZA, Pencegahan serta Penanggulangan HIV/AIDS, serta Penggunaan jamban. Selain itu, sasaran akan diberikan kesempatan berdiskusi dan tanya jawab terkait kajian yang diberikan.

2. Demonstrasi

Sasaran akan melihat demonstrasi dengan menggunakan alat dan bahan untuk mencuci tangan dengan benar, serta melihat prosedur langkahlangkah mencuci tangan. Tujuannya adalah agar sasaran mampu memahami prosedur tersebut sehingga dapat diterapkan.

3. Simulasi

Setelah mendapatkan kajian materi dan melihat demonstrasi, sasaran akan dibagi dalam kelompok kecil untuk mempraktikkan metode tersebut dalam satu kali pertemuan untuk membuat skenario kemudian berlatih sosialiasasi untuk mempromosikan perilaku hidup bersih dan sehat. Tujuan dari tahap ini adalah agar sasaran mampu menerapkan dengan benar materi PHBS yang telah diterima. Agar kegiatan lebih terarah, maka akan dilaksanakan monitoring dan evaluasi pada praktik tersebut.

4. Monitoring Evaluasi

Sasaran dapat berkonsultasi dengan tim pelaksana terkait aplikasi atau praktek dari skenario kasus terkait indikator-indikator dalam PHBS yang telah dilakukan. Tim pelaksana dapat mengevaluasi serta mengetahui target kompetensi yang telah dicapai sasaran. Tim pelaksana akan memonitoring secara langsung di lapangan dimana sasaran mampu menerapkan perilaku bersih dan sehat. Proses monitoring dan evaluasi penerapan PHBS juga akan terus dilakukan selama periode kegiatan pengabdian.

Keberlanjutan dari program ini sangat diharapkan untuk menjadi bahan Promosi Kesehatan di tingkatan Wilayah Lingkungan Sekolah. Sasaran akan memberi feedback dan akan menjadi bahan evaluasi. Hasil evaluasi tersebut digunakan sebagai salah satu pertimbangan untuk mengadakan program selanjutnya. Kegiatan serupa akan dil- 
Available online at https://jurnal.stmikroyal.ac.id/index.php/jurdimas

aksanakan secara berkelanjutan dan diharapkan akan terbentuk kegiatan dalam rangkaian Promosi Kesehatan kepada masyarakat awam dan akan merambah ke unsur lain dalam PMI serta komunitas lain di Kota Magelang.

\section{PEMBAHASAN}

Program Kemitraan Universitas dilaksanakan selama 3 bulan mulai dari persiapan hingga penyusunan laporan. Persiapan dilaksanakan pada tanggal 20 Januari 2019 melalui koordinasi dengan Ketua Markas PMI Kota Magelang bersama Komandan Korps Sukarelawan (KSR) beserta Pengurus Bidang Palang Merah Remaja dan Sukarelawan PMI Kota Magelang. Tim PKU bertemu dengan pihak Mitra yaitu PMI Kota Magelang dengan tujuan untuk menyampaikan rencana kegiatan dengan melibatkan Palang Merah Remaja (PMR) yang berada di wilayah binaan PMI Kota Magelang. Kegiatan tersebut disambut dengan baik dan segera akan menyampaikan rekomendasi kegiatan yang meliputi pemberian materi, pelatihan serta simulasi ini kepada anggota PMR, dalam hal ini dipilih target peserta yaitu PMR Madya yaitu PMR pada tingkat atau jenjang Sekolah Menengah Pertama. Pada kesempatan tersebut, tim PKU juga menyampaikan harapan dan rencana jangka panjang untuk memberikan kegiatan terkait Perilaku Hidup Bersih dan Sehat kepada para siswa Sekolah Menengah Pertama yang tergabung dalam anggota PMR Madya di wilayah Binaan PMI Kota Magelang.

Pada tanggal 03 Februari 2019, tim pelaksana Program Kemitraan Universitas mengadakan survey dan koordinasi melalui Ketua Markas PMI Kota Magelang beserta Komandan Korps Su- karelawan (KSR) terhadap calon peserta yaitu para siswa anggota PMR Madya yang ada di wilayah Binaan PMI Kota Magelang. Melalui survey tersebut, didapat data driver yang bersedia untuk mengikuti pelatihan. Hasil survey yang dilaksanakan di diperoleh 30 siswa yang bersedia menjadi peserta.

Pada tanggal 10 Februari 2019, Tim Pelaksana memberikan undangan pelatihan untuk peserta pelatihan sesuai hasil koordinasi dengan Ketua Markas PMI Kota Magelang dan Komandan Korps Sukarelawan (KSR). Setelah itu tim pelaksana juga berkoordinasi dengan calon peserta untuk mengkonfirmasi kehadiran. Tim pelaksana juga mulai mempersiapkan perlengkapan pelatihan yakni materi, tempat, konsumsi, dan administrasi.

Pelaksanaan pelatihan dibagi menjadi empat tahap. Pelatihan pertama dilaksanakan pada tanggal 16 Februari 2018 di Ruang Kelas SMPN 03 Kota Magelang pukul 14.00-16.30 WIB. Namun terdapat beberapa peserta yang tidak dapat menghadiri pelatihan. Pelatihan tahap 1 dilaksanakan dengan metode Brainstorming, ceramah, serta dilanjutkan dengan Demonstrasi.

Sesi ini diawali dengan diskusi permasalahan yang dihadapi oleh peserta dalam salah satu perilaku hidup bersih dan sehat seperti salah satu contohnya adalah kebiasan mencuci tangan. Tidak hanya itu, peserta juga berbagi pengalaman terkait perilaku atau kebiasaan cuci tangan yang pernah mereka terapkan dalam kehidupan sehari-hari. Setelah itu, pemateri yakni Ns Eka Sakti Wahyuningtyas, MKep, memberi materi terkait Konsep Cuci Tangan dan Langkahlangkah baik dan benar (7 langkah) cuci tangan menurut WHO sebagai salah satu bentuk perilaku hidup bersih dan sehat (PHBS). Topik ini menjadi bahan yang 
Available online at https://jurnal.stmikroyal.ac.id/index.php/jurdimas

sangat menarik terlihat dari respon peserta anggota Palang Merah Madya yang belum dapat menjawab beberapa pertanyaan inisiasi yang diajukan pemateri walaupun topik dinilai sangat sederhana. Kemudian, peserta mengerjakan soal pretest yang terdiri dari 3 aspek, yaitu konsep dasar, prinsip dan tahapan, dan penerapan. Rata-rata skor pre-test dari keseluruhan peserta adalah 60 .

Sesi demonstrasi diawali dengan pemateri menayangkan video terkait 7 (tujuh) langkah cuci tangan dan kemudian memberikan contoh melalui demonstrasi cuci tangan. Langkah-langkah cuci tangan sesuai petunjuk WHO (World Health Organization). Setelah memperagakan 7 langkah cuci tangan tersebut, peserta yaitu anggota PMR Madya secara berkelompok memperagakan atau mendemonstrasikan 7 langkah cuci tangan tersebut. Setelah dilakukan evaluasi, seluruh peserta mampu mendemonstrasikan dengan langkah yang sesuai petunjuk dengan baik dan benar. Feedback diberikan untuk menyempurnakan demonstrasi yang diperagakan peserta.

Pelatihan kedua dilaksanakan pada tanggal 5 Maret 2019 di Ruang Kelas SMPN 04 Kota Magelang pukul 14.0016.00 WIB. Pelatihan tahap 2 dilaksanakan dengan metode ceramah dan diskusi dengan Penyalahgunaan Rokok Pada Remaja. Pada sesi ini, peserta diberikan materi terlebih dahulu terkait Bahaya dan Efek Rokok Bagi Kesehatan oleh Ns Eka Sakti Wahyuningtyas, MKep melalui metode ceramah.

Setelah memahami prinsip melalui ceramah terkait materi serta tahapan pembelajaran terkait Bahaya dan Efek Merugikan Rokok Bagi Remaja, peserta dibagi menjadi kelompok. Setelah itu, setiap kelompok dilaksanakan diskusi atau Brainstorming untuk menyampaikan pendapat serta opini tentang topik "Rokok di Masa Kini Bagi Remaja". Setiap kelompok wajib menanggapi opini atau pendapat dari kelompok lain. Proses Diskusi berjalan dengan lancar, setiap peserta anggota PMR Madya berperan aktif dalam diskusi tersebut. Feedback diberikan untuk menyempurnakan hasil diskusi dan memberikan kesimpulan terhadap topik yang diberikan peserta.

Pelatihan tahap ketiga dilaksanakan pada tanggal 13 Maret 2019 di Ruang Kelas SMPN 04 Kota Magelang pukul 14.00-16.00 WIB. Terdapat beberapa peserta yang tidak dapat menghadiri pelatihan dikarenakan beberapa peserta anggota PMR Madya sedang mempersiapkan acara Jumbara (Jumpa Bakti Gembira) PMR Se-Kota Magelang yang diadakan oleh PMI Kota Magelang. Pelatihan tahap 3 dilaksanakan dengan metode ceramah dan diskusi.

Sesi ini diawali dengan paparan materi dengan topik yaitu materi HIV AIDS. Materi disampaikan melalui metode ceramah oleh pemateri yaitu Ns Estrin Handayani, MAN. Materi HIV AIDS meliputi konsep dasar penyakit, tanda dan gejala, cara penularan, serta penanggulangan atau pencegahan HIV AIDS. Kemudian narasumber memberikan quiz singkat seputar mitos atau fakta yang berkaitan dengan materi. Peserta dibagi menjadi beberapa kelompok quiz tersebut. Peserta anggota PMR Madya terlihat antusias dan tertarik dengan metode pemberian materi yang telah diberikan pada kesempatan tersebut. 
Available online at https://jurnal.stmikroyal.ac.id/index.php/jurdimas

Tabel 1. Nilai Pre-test dan Post-test

\begin{tabular}{rccc}
\multicolumn{1}{c}{ Aspek } & \multicolumn{2}{c}{ Rata-rata nilai } & Prosentase \\
\cline { 2 - 4 } & Pre-test & Post-test & Peningkatan \\
\hline Pengetahuan dasar & 60 & 85 & $42 \%$ \\
\hline Prinsip \& tahapan & 62,5 & 90 & $44 \%$ \\
\hline Penerapan & 55 & 80 & $46 \%$ \\
\hline
\end{tabular}

Peserta terlihat memahami dan mampu menjelaskan dengan baik seputar topik yang telah diberikan. Feedback diberikan untuk menyempurnakan kegiatan yang dilaksanakan peserta. Semua peserta anggota PMR Madya dapat menghadiri pelatihan. Pelatihan tahap 4 dilaksanakan dengan metode ceramah serta simulasi. Sesi ini diawali dengan pemberian materi terkait penggunaan jamban bersih dan sehat. Setelah itu, peserta dibagi menjadi menjadi beberapa kelompok dilanjutkan dengan pemberian tugas untuk membuat poster sebagai bahan media pendidikan kesehatan yang berkaitan dengan topik. Seluruh peserta bergantian dalam kelompok untuk mendemonstrasikan bentuk pendidikan kesehatan dengan menggunakan media poster sederhana. Feedback diberikan untuk menyempurnakan simulasi yang diperagakan peserta. Sebagian besar tahapan pembelajaran sudah sesuai dengan materi yang telah diajarkan dan diperagakan atau demonstrasi. Pada tahap akhir, peserta juga diberikan post-test untuk mengevaluasi hasil pembelajaran.

Berdasarkan tabel di atas, ratarata peningkatan aspek Pengetahuan Dasar setelah diberi treatment adalah $42 \%$ dengan nilai rata-rata pre-test 60 dan post-test 85. Sedangkan peningkatan aspek Prinsip dan Tahapan yaitu 44\% yang semula 62,5 menjadi 90 untuk ratarata tiap tes. Aspek penerapan menunjukkan nilai rata-rata awal 55 dan meningkat menjadi 80 atau terdapat peningkatan sebesar 46\%. Dengan demikian, pelatihan dapat dikatakan berhasil karena mampu meningkatkan kemampuan dan pengetahuan peserta. Terlepas dari hal tersebut, terdapat faktor pendukung dan hambatan dalam pelaksanaan kegiatan. Dukungan dari organisasi Palang Merah Indonesia (PMI) Kota Magelang atau sekolah dengan mengirimkan anggota PMR Madya sebagai peserta menjadi salah satu faktor pendukung terlaksananya kegiatan ini. Kepala Markas PMI Kota Magelang juga turut berperan dengan memberikan ijin kepada tim pelaksana. Para peserta pun sangat antusias dalam mengikuti pelatihan karena menyadari betul manfaat yang mereka dapatkan dalam turut memperhatikan bagian-bagian dalam Perilaku Hidup Bersih dan Sehat (PHBS) dengan menerapkan prinsipprinsip tersebut untuk dapat menjadi contoh perilaku bagi teman sebaya di lingkungan Sekolah. Namun terdapat hambatan yang tim pelaksana temui terutama pada hari pelaksanaan dimana terdapat beberapa sekolah yang belum dapat berperan menjadi anggota pelatihan karena terkendala kegiatan sekolah.

\section{SIMPULAN}

Tujuan dari kegiatan ini berhasil dicapai dilihat dari meningkatnya pemahaman dan penerapan program hidup bersih dan sehat anggota Palang Merah Remaja (PMR) Madya. Berdasarkan hasil pre-test dan post-test, diketahui bahwa rata-rata peningkatan aspek Pengetahuan 
Available online at https://jurnal.stmikroyal.ac.id/index.php/jurdimas

Dasar setelah diberi treatment adalah $42 \%$ dengan nilai rata-rata pre-test 60 dan post-test 85. Sedangkan peningkatan aspek Prinsip dan Tahapan yaitu 44\% yang semula 62,5 menjadi 90 untuk ratarata tiap tes. Aspek penerapan menunjukkan nilai rata-rata awal 55 dan meningkat menjadi 80 atau terdapat peningkatan sebesar 46\%. Dengan demikian, pelatihan dapat dikatakan berhasil karena mampu meningkatkan kemampuan dan pengetahuan peserta.

Dengan demikian, secara keseluruhan tujuan dari pelatihan ini berhasil dicapai. Berdasarkan survei awal, masih kurangnya pengetahuan dan perlunya penerapan perilaku hidup bersih dan sehat dalam lingkungan sekolah serta sebagian besar anggota PMR Madya masih perlu mendapatkan pengetahuan terkait beberapa indikator Perilaku Hidup Bersih dan Sehat di lingkungan sekolah mereka. Penanaman nilai-nilai PHBS di sekolah merupakan kebutuhan mutlak dan dapat dilakukan melalui pendekatan lewat PMR sebagai salah satu bentuk Tri Bhakti PMR yaitu menjaga kesehatan lingkungan. Setelah diberi treatment berupa pelatihan ini, peserta mampu menerapkan meningkatkan perilaku hidup bersih dan sehat untuk masyarakat di wilayah lingkungan sekolah. PMR Madya sebagai bagian dari generasi penerus PMI yang turut serta dalam menjaga kesehatan lingkungan. Terciptanya sekolah yang bersih dan sehat sehingga siswa, guru dan masyarakat lingkungan sekolah terlindungi dari berbagai gangguan dan ancaman penyakit.

\section{UCAPAN TERIMA KASIH}

Tim Pelaksana mengucapkan terima kasih atas dukungan dan kerjasama yang telah diberikan pihak
PMI Kota Magelang dan PMR Madya di wilayah Binaan PMI Kota Magelang. Kami juga mengucapkan terimakasih kepada Lembaga Pengembangan Penelitian dan Pengabdian Masyarakat (LP3M) Universitas Muhammadiyah Magelang yang telah memberikan support atas keberlangsungan kegiatan yang merupakan hibah Program Kemitraan Universitas (PKU).

\section{DAFTAR PUSTAKA}

GYTS. (2014). Global Youth Tobacco Survey ( GYTS ) Indonesia Report, 2014. World Health Organization. Retrieved from http://www.searo.who.int/tobacco/d ocuments/ino_gyts_report_2014.pdf

Kesehatan, F., Universitas, M., \& Ratulangi, S. (2017). Bersih Dan Sehat ( Phbs ) Pada Siswa Sekolah Dasar Inpres Sinuian Pendahuluan Perilaku Hidup Bersih dan Sehat adalah perilaku kesehatan yang dilakukan atas kesadaran sehingga anggota keluarga atau keluarga dapat menolong dirinya sendiri dibidang kesehatan, (December).

http://www.pmi-jakarta.org/ Palang Me rah Indonesia 